\title{
Pengembangan Teknik Peran Seorang Aktor Untuk Pementasan Monolog Melalui Sistem Stanislavski dalam Buku an Actor Prepares and Building a Character
}

\author{
Roci Marciano \\ Sekolah Tinggi Kesenian Wilwatikta Surabaya \\ rocimarci@gmail.com
}

\begin{abstract}
Abstrak
Tujuan penelitian Teknik Peran Seorang Aktor Untuk Pementasan Monolog Melalui Sistem Stanislavski An Actor Preapares And Building A Character ini dilakukan ialah, untuk mengembangkan model pembelajaran pada mata kuliah Totalitas Keaktoran yang ditempuh oleh mahasiswa semester lima. Pengembangan Teknik Peran Seorang Aktor Untuk Pementasan Monolog Melalui Metode Stanislavski An Actor Preapers And Building A Character penting untuk di pelajari saat ini. Karena penelitian memberikan dampak positif bagi seorang mahasiswa khususnya dan masyarakat luas pada umumnya yang mengambil minat keaktoran. Kecerdasan yang bisa dipelajari dalam belajar monolog tentu saja bukan hanya demi keberanian seorang aktor tampil sendirian di atas panggung dengan menyampaikan kisah atau cerita. Tetapi nilai yang paling berharga dari penemuan teknik peran ini adalah, seorang aktor bisa memulai pelatihannya dengan tersistem, teratur dan terprogram. Karena monolog juga memiliki dampak yang positif untuk dipelajari, seperti sebagai mahasiswa atau manusia mampu menghapalkan hasil pemikiran seorang penulis naskah, merespon segala tatanan artistik dengan kecerdasan lahiriah dan batiniah sebagai perangkat keaktoran untuk disampaikan kepada penonton. Oleh sebab itu teknik-teknik dalam pelatihan seorang aktor untuk mewujudkan pementasan monolog dan monodrama tentu saja dibutuhkan, sehingga penelitian ini akan berguna bagi mahasiswa STKW Surabaya khususnya, dan seluruh mahasiswa teater yang ingin pentas monolog pada umumnya.
\end{abstract}

Kata kunci: monolog; aktor; teater; drama; stanislavski

\begin{abstract}
The aim of the research is the Technique of the Role of an Actor for Monologue Staging Through the Stanislavski An Actor Preapares And Building A Character System, to develop learning models on courses in the Actual Totality taken by fifth semester students. Development of an Actor's Role Technique for Monologue Staging Through the Stanislavski An Actor Preapers And Building A Character Method is important to learn at this time. Because research has a positive impact on a student in particular and the general public in general who take an interest in activity. Intelligence that can be learned in learning a monologue is of course not only for the courage of an actor to appear alone on the stage by telling stories or stories. But the most valuable value of discovering this role technique is that an actor can start his training in a systematic, organized and programmed manner. Because monologues also have a positive impact to learn, such as students or humans able
\end{abstract}


to memorize the thoughts of a scriptwriter, respond to all artistic orders with physical and inner intelligence as instruments of accuracy to be conveyed to the audience. Therefore the techniques in training an actor to realize monologue and monodrama performances are of course needed, so this research will be useful for STKW Surabaya students in particular, and all theater students who want to perform monologues in general.

Keywords: monoloques; actor; theater; drama; stanislavski

\section{PENDAHULUAN}

Belum ada buku khusus baik itu berdasarkan penelitian maupun yang menuliskan tentang teknik peran untuk pementasan monolog. Kesulitan ini disebabkan karena dalam menerapkan materi dan metode keaktoran masih sangat abstrak, tidak ada rumusan yang jelas dalam pembelajaran, sedangkan peserta didik (mahasiswa) sebagian besar tidak memiliki modal dasar yang kuat pada materi keaktoran dalam hal ini adalah monolog. Perlu upaya untuk mengatasi kesulitan ini, dengan memberikan model dan media pembelajaran yang sesuai, agar materi yang abstrak tersebut bisa dikongkretkan seperti buku teknik peran untuk pementasan monolog. Sistem seni peran Stanislavski merupakan buku wajib dalam dunia keaktoran secara umum, khususnya untuk kebutuhan seni peran dalam teater. Oleh sebab itu perlu kajian khusus untuk disesuaikan dengan kebutuhan pementasan Monolog. Penelitian ini juga akan mengembangkan modul pembelajaran pemeranan yang berorientasi pada teknik Stanislavski, Hal ini dilakukan karena metode Stanislavski sangat efektif bagi pecinta monolog, khususnya bagi mahasiswa Jurusan teater STKW Surabaya.

Kontribusi pada ilmu teater saat ini tentu saja penting diperhatikan, sebab jika dijadikan sebagai media pendidikan karakter, maka peserta didik tersebut akan sekaligus memerankan karakter yang akan dimainkan, dinilai dan diapresiasi oleh penonton. Penemuan Teknik Peran Seorang Aktor Untuk Pementasan Monolog Melalui Sistem Stanislavski dalam buku An Actor Prepares And Building Character ini, menghasilkan pembelajaran yang sangat membantu mahasiswa khususnya yang mengambil mata kuliah monolog. Mahasiswa dapat dengan efektif bisa melakukan pembelajaran secara mandiri, efektif dan praktis serta dapat mengembangkan kemampuan monolog dalam berperan dengan menggunakan sistem Stanislavski sebagai pembelajaran untuk mewujudkan kemandirian dalam berkehidupan. Oleh sebab itu sebagai insan yang sedang melatih dan menempa diri dalam kemandirian, perlu rasanya belajar tentang monolog.

Bila diartikan dari bahasa Inggris monologue artinya berbicara sendiri, dan kata monolog ini sendiri telah diserap dalam bahasa Indonesia yang juga diartikan sebagai pembicaraan yang dilakukan dengan diri sendiri atau seorang pelaku tunggal dalam sandiwara yang membawakan percakapan seorang diri. Mengutip catatan Alterman dalam Creating your own monologue mengatakan; A long monologue or 
monodrama is a one-person play. Monodramas can be a powerful form of theater (Alterman, 2005: 4). Maka berdasarkan kutipan ini mengatakan, bahwa pementasan yang dilakukan manusia seorang diri atau seorang aktor di atas panggung disebut dengan monolog, dan monodrama ini memiliki kekuatan tersendiri sebagai bentuk seni pertunjukan.

Penulis juga sepakat bahwa monolog sesungguhnya adalah kata hati yang diformulasikan dalam bentuk cakapan, dan kata hati ini dalam drama dibagi tiga macam diantaranya ada monolog, soluloque dan aside (Abdullah, 2000: 86). Monolog adalah berbicara sendiri dan lawannya ialah dialog. Monolog juga suara hati yang diucapkan, dan seyogyanya bisa didengar oleh penonton dari bangku yang paling depan sampai bangku yang paling belakang di gedung pertunjukan. Hal ini juga seiriama dengan apa yang ditulis oleh seniman teater Indonesia Nano Riantiarno di dalam pengantar buku Sphinx Triple X yang mengatakan;

Tradisi 'monodrama' Yunani klasik itu, kemudian dilanjutkan oleh Wiliam Shakespeare dalam banyak karya dramanya. Tapi Shakespeare menyebutnya sebagai solilog. Atau soliloque. Itulah adegan ketika seorang pelakon mengungkapkan fikiran dan perasaannya, sendirian, tanpa kehadiran pelakon lain. Sebagaimana mono drama dalam karya Aeschylus, soliloque juga masih merupakan bagian dari sebuah drama panjang (Riantiarno, xiv; 2004).
Sebagai suatu genre dalam kesenian teater saat ini, monolog penting untuk dipelajari khususnya dikalangan Mahasiswa, baik dari sajian dalam bentuk pertunjukan, maupun dari segi aliran sebagai keilmuan. Karena perkembangan monolog tersebut mengalami banyak bentuk, seperti teater yang juga terbagi dalam teater realis yang memuat teater realisme konvensional, realis epik dan realis sugestif. Begitu juga dengan teater non realis yang memuat kotemporer, eksperimental, tradisional, absurd, dadais, surealis, postrealis dll. Sama halnya dengan monolog yang sudah terbagi dalam beraneka ragam bentuk istilah seperti monolog, mono play, one man show, teater solo dan masih banyak lagi istilah yang menjadi perdebatan di kalangan para teaterawan tanah air. Namun pada dasarnya semua pementasan yang dilakukan oleh seoarang aktor di atas panggung bersumber dari kata monolog, yakni seorang manusia yang menceritakan sesuatu, dengan menggunakan kata dan tubuh sebagai senjata komunikasinya.

Mengapa monolog ini menjadi penting? Sebab di dalam Mata Kuliah Prodi Teater STKW monolog adalah mata kuliah wajib, selain itu Kementerian Pendidikan Tinggi juga selalu mengadakan lomba Monolog dalam rangakaian acara Peksiminas (Pekan Seni Mahasiswa Nasional) yakni perlombaan monolog mahasiswa tingkat Nasional. Begitu juga kampus-kampus dan sanggar-sanggar yang ada di Negeri ini, selalu mengadakan festival monolog atau monodrama, akan tetapi dalam prakteknya banyak terjadi perdebatan dikalangan penyelenggara akan monolog itu sendiri. Juga banyaknya mis-komunikasi penerapan teknik yang dilakukan oleh seorang 
aktor dalam bermain, dan yang tampak hanya demonstrasi visual, namun tidak menjadi utuh sebagai demonstrasi pementasan monolog dimana keaktoranlah yang seharusnya menjadi poin utama dalam pementasan monolog.

Oleh sebab itu penting rasanya diadakan suatu penelitian tentang Pengembangan Teknik Peran Seorang Aktor Untuk Pementasan Monolog Melalui Metode Stanislavski dengan bukunya Actor An Preapere And Building A Character. Sebab banyak peminat yang melakukan suatu kegiatan monolog, tetapi tidak mengetahui landasan secara teoritis tentang teknik bermain monolog itu sendiri. Di atas panggung para aktor kemudian hanya sekedar menyampaikan cerita, tetapi tidak menghidupkan peristiwa cerita. Hal inilah yang kemudian menjadi tantangan bagi aktor monolog, bagaimana caranya seorang diri bisa menghidupkan beraneka ragam bentuk, kisah dan cerita di atas panggung. Bisa jadi tampai terasing dalam sepi, atau justru tampak ramai walau sendiri. Seorang aktor harus mampu menghidupkan tokoh, ruang, latar, tata busana, tata cahaya, tata panggung dan sebagainya.

Pembelajaran dalam Totalitas Pentas monolog yang ditempuh oleh Mahasiswa selama ini masih menggunakan teknik improvisasi yang belum mempunyai metode terukur atau belum mempunyai pembelajaran yang berlandaskan teori yang sudah teruji, hal ini disebabkan karena belum ada kajian khusus yang memperdalam teori dan teknik peran untuk pementasan monolog. Pelaku seni yang mempunyai latar belakang akademisi seni sangatlah berbeda dengan pelaku non akademis dalam penyikapan proses untuk melakukan pementasan monolog. Akademisi membutuhkan sebuah metode pembelajaran yang efektif dan terukur dalam sebuah pembelajaran pemeranan, sehingga mampu melakukan pemeranan dengan langkah yang jelas dan dapat menjalankan peran tokoh yang baik. Akademisi yakni mahasiswa seni teater diwajibkan mempunyai landasan metode yang jelas sehingga mahasiwa atau pelaku seni pelajar dapat mempelajari seni peran dengan baik. Harapannya pelaku non akademis juga bisa terinspirasi dengan sistem yang telah ditemukan dan diuji secara akademis. Dalam penelitian ini tentu saja tidak ada maksud untuk mengkotak-kotakkan antara seni akademis dan non akademis, akan tetapi maksud dari kajian ini memang terutama ditujukan pada Mahasiswa yang mengambil bidang khusus teater secara umum dan pemeranan secara khususnya.

Dalam khasanah ilmu teater modern, teknik peran yang telah dijadikan pijakan dalam pembelajaran peran salah satunya adalah teknik peran Stanislavski. Stanislavski mempunyai langkah yang jelas dan terukur dalam mempelajari seni peran. Hal inilah yang kemudian mendorong penulis untuk mengembangkan model pembelajaran totalitas pentas keaktoran melalui sistem Stanislavski. Oleh karena itu solusi yang ditawarkan agar mahasiswa Jurusan teater bisa melakukan peran dengan mudah yaitu dengan mengembangkan model pembelajaran teknik peran yang jelas dengan berorientasi pada sistem Stanislavski dan harapanya model pemebelajaran ini dapat dijadikan bahan ajar untuk menunjang kemampuan akademik Mahasiswa yang mengambil minat keaktoan. 


\section{METODE}

Jenis penelitian yang sengaja dipilih untuk meningkatkan teknik peran seorang aktor untuk kebutuhan monolog ini ialah penelitian kualitatif, yang pada dasarnya digunakan untuk menghasilkan berupa model pembelajaran dan perangkatnya. Untuk mengetahui kualitas produk yang dikembangkan, digunakan tiga ukuran yaitu kevalidan, kefektifan, dan kepraktisan (Sugiyono, 2011:26). Selain itu, penelitian kualitatif juga didasarkan pada kata-kata dan gambaran holistik (Moleong, 2011: 6). Sehingga penelitian ini akan mencoba sedetil mungkin menghadirkan objek teliti, baik itu disertai dengan nama dan bentuk, sekaligus disertai dengan analisis yang penulis temukan pada saat penelitian.

Mengapa menggunakan metode penelitian kualitatif? Tentu saja didasari dengan alasan yang jelas, sebab penelitian yang dilakukan berorientasi pada teori yang sudah ada. Penelitian kualitatif seperti yang sudah diketahui, teori dibatasi pada pengertian. Suatu pernyataan yang sistematis berkaitan dengan perangkat proporsi yang berasal dari data dan diuji kembali secara empiris (Moleong, 2007:14). Pengujian secara empiris inilah yang justru akan menghidupkan kembali pengetahuan tersebut, apakah teori yang tersaji masih bisa digunakan atau tidak, dan jika masih bisa digunakan, apakah butuh penyesuaian dengan kebutuhan zaman saat ini. Metode kualitatif sebagai sebuah prosedur penelitian menghasilkan deskriptif, baik berupa kata-kata yang tertulis, maupun perilaku yang dapat diamati berkaitan dengan objek penelitian. Maka dengan kekuatan katakata yang penulis punya, akan mengungkapakan sejujur-jujurnya hasil penelitian ini.

Dalam perkembangannnya tidak menutup kemungkinan bahwa metode Penelitian yang digunakan adalah kualitatif rasionalistik, sedang pendekatan proses identifikasi masalah, menggunakan metode kualitatif intepretatif, karena berkaitan dengan metode penafsiran yang dilakukan dalam penelitian ini. Menurut Nyoman Kutha Ratna (2010), penelitian kualitatif sebagai metode ilmu sosial (ilmu humanoria khususnya kajian budaya) perlu diperluas dengan cara penafsiran yang secara khas bersifat tekstural yang dikenal sebagai kualitatif interpretatif (Ratna, 2010; 306). Maka dalam penelitian nantinya, penulis tidak serta merta menuliskan secara mentah apa yang ada di dalam buku, akan tetapi juga menuliskan hasil analisis dan uji empiris yang penulis lakukan selama penelitian.

Penulis juga melakukan survey untuk menentukan kelas yang akan dijadikan sampel. Menjelaskan kepada peserta didik tentang model yang akan dikembangkan. Kemudian melakukan kegiatan model pembelajaran yang berorientasi pada sistem seni peran Stanislavski dalam buku An Actor prepeare and Building Character dari sintak pertama sampai terakhir. Selanjutnya melakukan evaluasi sehubungan dengan materi dan model pembelajaran yang dikembangkan dengan hasil respon yang diberikan oleh peserta didik, dan dilanjutkan dengan menganalisis hasil belajar untuk uji kevalidan skala kelompok besar. Subjek uji coba penelitian ini adalah mahasiswa Jurusan teater Sekolah Tinggi Kesenian Wilwatikta Surabaya. 
Adapun populasi dan yang menjadi sampel dalam penelitian ini adalah mahasiswa prodi Teater yang berjumlah 8 orang, khususnya mahasiswa semester lima yang mengambil mata kuliah totalitas keaktoran, selain dari Mahasiswa Teater STKW Surabaya, penulis juga mengujikan materi penelitian ini di setiap workshop seni peran. Tidak menutup kemungkinan sambil mengajar pada mata kuliah ini metode Stanislavski akan diajarkan. Pengumpulan data dalam penelitian ini menggunakan metode dan teknik Validasi model dan perangkat pembelajaran yang digunakan untuk menilai kualitas model dan perangkat yang dikembangkan.

Mahasiswa menggunakan model pembelajaran Sistem Stanislavski, kemudian penulis selaku Dosen pangampu menilai menggunakan sistem penilaian teknik keaktoran untuk pementasan monolog. Hasil yang dicapai dalam penelitian ini adalah mahasiswa bisa menerapkan teknik pemeranan Stanislavski untuk pementasan monolog. Secara otomatis penulis juga menuliskan hasil penelitian dalam bentuk jurnal, modul dan buku pembelajaran pemeranan berorientasi valid, praktis, dan efektif. Kriteria kevalidan, keefektifan, dan kepraktisan modul. Seperti apa yang telah dituliskan dalam jurnal ini, bahwa hasil penelitian yang telah dilakukan penulis tuliskan sebagian di Jurnal ini dengan kapasitas tulisan yang dibutuhkan, untuk kelengkapannya ada pada buku Teknik Monolog. Di dalam buku teknik monolog penulis juga memberikan contoh naskah monolog, dan teknik peran Stanislavski lengkap dengan tutorial tahapan yang bisa dilakukan oleh seorang aktor.

\section{HASIL DAN PEMBAHASAN}

$$
\text { Menyikapi uraian pada }
$$

pendahuluan di atas, menimbulkan berbagai pertanyaan kritis di dalam diri penulis untuk merumuskan permasalahan-permasalahannya.

Adapun permasalahan tersebut adalah sebagai berikut: Bagaimana mengembangkan metode teknik peran Stanislavski untuk kebutuhan pementasan monolog? Bagaimana menyaring teknik peran yang dicetuskan oleh Stanislavski dalam bukunya actor and preapere dan Building A Character untuk kebutuhan teknik peran monolog? Sampai saat ini belum ditemukan ada buku khusus yang menciptakan teknik pemeranan untuk pementasan monolog berdasarkan metode pelatihan teknik peran Stanislavski. Oleh sebab itu, dalam catatan yang singkat ini penulis akan menjelaskan tentang teknik pemeranan untuk persiapan pementasan monolog, dan apa itu monolog secara teoritis.

Menurut Lanvord Wilson dalam Shengold catatan bukunya The Actor's Book Of Contemporary Stage Monologues mengatakan bahwa monolog It's almost a one-act play, (Shengold, 1987: 324). Kutipan ini jelas mengatakan bahwa seorang aktor yang sedang berakting di atas panggung sendirian, maka bisa disebut dengan monolog. Akting dalam hal ini tentu saja ada kata-kata yang disampaikan melalui ekspresi, mengungkapkan apa yang dirasakan, 
baik diri sebagai diri, diri sebagai aktor, maupun diri yang berakting sebagai tokoh. Sebab dalam pertunjukan yang dilakukan oleh seorang manusia di atas panggung tentu saja tidak bisa semua dikatakan monolog, sebab ada tari tunggal, pantomime dan permainan sulap. Bahkan pidato terkadang juga disebut oleh sebagian orang sebagai pertunjukan monolog. Hal ini tentu saja tidak salah, apa bila seorang penceramah disebut sebagai monolog masih bisa di terima, tapi apakah seorang penceramah disebut sebagai pertunjukan monolog? Itu yang keliru, sebab monolog adalah seorang aktor yang sedang memainkan peran dan berkabar berita terhadap penonton (bermain peran dalam hal ini seorang aktor diharap bisa "menjadi" tokoh).

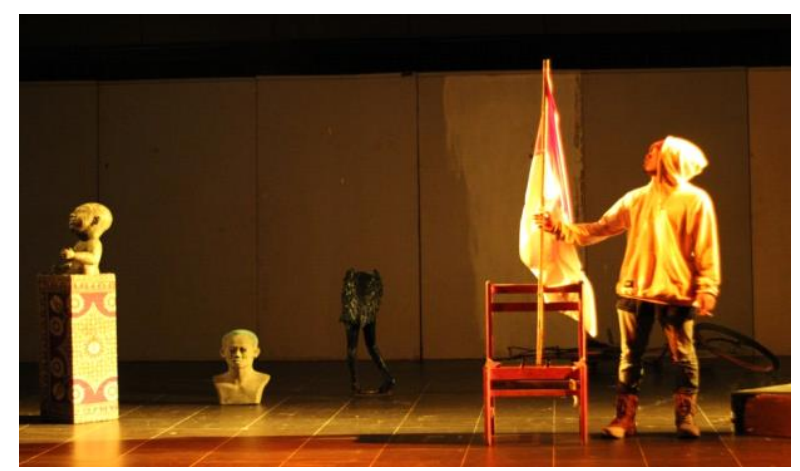

Gambar 1. Pementasan Monolog berdasarkan teknik Stanislavski dengan judul Bangkit Pemuda Oleh Abiyan Renardi, karya: Roci Marciano (foto oleh: rifah Isyah; 2019).

Menurut Tina Howe dalam Shengold mengatakan; A monologue has to do with revealing things that the character has been unable to reveal before. So it's a very precious moment (Shengold, 1987: 331). Penulis merasa sepakat dengan kutipan ini, karena belajar monolog juga memperkuat karakter sebagai manusia. Sehingga harapannya melalui pembelajaran monolog ini pula, latihan kemandirian dari mahasiswa bisa diwujudkan, baik bertanggungjawab terhadap diri sendiri, maupun kepada orang lain, karena teater meskipun pementasan monolog, tetap menjaga kolektivitas antar sesama awak panggung. Mengapa demikian? Sebab aktor monolog juga sangat membutuhkan petugas teknis yang bisa membantu untuk mendukung pertunjukannya, baik itu team setting, lighting, tata busana, produksi, penjaga pintu dan buku tamu, stage manager, penata rias dan masih banyak lagi yang dibutuhkan oleh seorang aktor monolog untuk bersinergi dengan orangorang di sekitarnya.

Harapannya jelas demi memberikan karya terbaik kepada penonton dan menyajikan pementasan dengan tidak mengganggu mood aktor dalam bermain. Semoga hal ini menjadi pertimbangan seorang aktor dengan serius, terutama yang ingin mementaskan monolog, itulah sebabnya mengapa monolog itu harus latihan dan untuk kebutuhan latihannya juga membutuhkan banyak tips dan trik keilmuan, khusunya ilmu teater, seperti kutipan Lehman yang sengaja penulis ambil di bawah ini;

Most studies of monologue proceed from the polarity of dialogue and monologue inherent to the analysis of drama, and because of their text-centred approach do not recognize the theatrical subtlety of monologies. Distinctions such as the one between 'soliloquies that are actional and those that are nonactional, or reflective' or the thesis that the convention of the soliloquy 'stylises a pathological extreme', 
talking to oneself, 'into a normal form of communicative behaviour' are informed by the schema of the more or less realistic representation of a dramatic action. (Lemann, 128: 2006)

Berdasakan kutipan di atas secara tidak langsung mengatakan bahwa monolog berasal dari soluloqui, yakni bagaimana seseorang mengungkapkan isi hatinya, namun dalam perkembangannya saat ini monolog tersebut berkembang dengan kebutuhan zamannya, bahkan dengan istilah-istilah yang bermunculan untuk mewadahi ekspresi aktor sebagai pembeda mana monolog berdasarkan soluloqoi dan mana yang telah berkembang hingga disebut dengan mono-play dan one man show, meskipun pada dasarnya tetap pentas tunggal yang menggunakan kata dan dramatik serta menceritakan pengalaman seorang aktor atau tokoh sendirian di atas panggung, di dalamnya disebut monolog. Jika permainan tanpa kata di lakukan oleh seorang aktor? Maka bisa di sebut dengan monolog apabila ia memainkan tokoh, baik itu tokoh bisu, atau permainan silent act, jika tidak ada tokoh dalam bentuk karakter yang dihadirkan seorang aktor dan manusia pentas sendirian, maka bisa dikatakan one man show, begitu juga dengan seorang aktor yang melakukan berbagai aneka karakter dalam petunjukannya sendirian, maka secara tidak langsung apa yang aktor itu lakukan disebut dengan monoplay atau one man play.

Adapun landasan teori yang dipilih dalam pendalaman tentang metode-metode Pengembangan Teknik Peran Seorang Aktor Untuk Pementasan Monolog Melalui Sistem Stanislavski, tentu saja buku-buku Stanislavaski itu sendiri, terutama buku $A n$
Actor Prepares And Building A Character. Selanjutnya dibutuhkan juga teori-teori seni peran yang telah terinspirasi dari sistem Stansislavski ini. Oleh sebab itu penulis juga menjadikannya sebagai teori sekunder, untuk bahan membantu menghayati, menjadi refrensi sebagai rujukan dan acuan dalam pendalaman seni peran. Adapun teknik peran monolog yang bisa penulis sajikan di dalam jurnal ini tidak selengkap dalam laporan penelitian, namun setidaknya yang tersaji di dalam jurnal ini juga bisa dimanfaatkan oleh calon aktor untuk belajar monolog sampai pada pementasan.

Buku Stanislavski yang berjudul An Actor Prepares, adalah buku yang menghadirkan metode baru bagi seni peran, dan secara sadar meninggalkan metode klasik, termasuk sistem bintang, seni deklamasi dan sentimentalis yang berlebih-lebihan. Konsepsi tentang seni peran di dalam buku Stanislavski ini juga memberi pengaruh yang besar kepada kalangan Teater Amerika sampai saat ini. Oleh sebab itu penulis merasa penting menggali teori seni peran yang dikembangkan khusus untuk persiapan seorang aktor tanah air dalam pementasan monolog. Karena di dalam buku ini belum ada secara spesifik metode atau sistem yang disiapkan untuk seorang aktor dalam pementasan monolog. Di dalam jurnal ini penulis mencoba adil, memasukkan tiga teknik Stanislavski berdasarkan buku Actor an prepeare dan tiga teknik yang sengaja dipilih dalam buku Building A Character (Pembangunan Watak). Adapun teknik yang akan penulis sampaikan dalam jurnal ini, dengan harapan calon aktor bisa melakukan tahap demi tahap seperti berikut ini: 


\section{Latihan fisik}

Bagi sebagian orang yang belum membaca buku Stanislavski yang bejudul Persiapan Seorang Aktor (akan disingkat menjadi PSA), mungkin merasa asing dengan adanya instruksi latihan fisik ini, bahwa ternyata Stanislavski juga menganjurkan calon aktor untuk mengolah fisiknya terlebih dulu. Hal ini penting untuk diketahui oleh seluruh calon aktor, karena buku ini memang dijadikan sebagai teori primer untuk Pengembangan Teknik Peran Seorang Aktor. Maka untuk Pementasan Monolog Melalui Sistem Stanislavski perlu rasanya penulis mengingatkan kepada seluruh calon aktor untuk melakukan eksplorasi seperti yang dikatakan Stanislavski dalam bukunya yang diterjemahkan oleh Asrul Sani; "untuk mengutarakan suatu kehidupan yang sangat halus dan terutama bersifat bawah sadar, kita harus menguasai aparat vokal dan fisik yang sangat peka dan dipersiapkan dengan baik sekali (Stanislavski, 15; 2007). Kata dipersiapkan dengan baik sekali tentu saja menjadi kebutuhan dasar yang harus dilakukan oleh seorang calon aktor.

Mengapa penulis mengatakan bahwa fisik adalah hal utama yang harus dikuasai oleh seorang aktor, sebab saat sekarang ini, dalam olah vokal sendiri sudah bisa dibantu oleh yang namanya teknologi, baik itu untuk memperjelas ucapan aktor di atas panggung, maupun untuk mengeraskan dan menyelaraskan suara aktor, alatnya bisa dengan adanya mick, kondensor, clip on atau sejenis teknologi lainnya. Tetapi tubuh? Tentu saja seorang aktor butuh kesabaran dan kecerdasan untuk mengolahnya, itulah mengapa latihan fisik seorang aktor menjadi poin utama yang harus diolah oleh calon aktor demi mewujudkan tokohnya untuk berakting. Seperti yang terungkap dalam buku George R. Kernoddle, Invitation To The Theater, 1996. Diterjemahkan oleh Dr. Dra. Yudiaryani, M.A. UPT Perpustakaan ISI Yogyakarta Tahun: 2005, 2007, 2008. Buku ini yang banyak menuliskan konsep-konsep Sistem Stanislavski, dan konsep-konsep keaktoran atau gaya pemeranan Stanislavski. Di dalam buku ini juga banyak keterangan tentang pementasan Drama dan bagaimana bermain peran, juga memuat perkembangan teater sejak zaman Renaisan.

Di buku ini tercatat bedanya aktor Stanislavski dan Brecht diantaranya; aktor Brecht bermain menurut keyakinan pribadi atas kerja dan usaha untuk "menghadirkan tokoh", bukan "menjadi tokoh" seperti yang diharapkan oleh Stanislavski (Kernoddle. 123; 2008). Oleh sebab itu latihan fisik untuk kebutuhan aktor pada akhirnya nanti juga akan berbeda dengan latihan fisik kebutuhan tokoh. Sebab kata menghadirkan dengan kata menjadikan tentu saja memiliki makna yang berbeda, seperti apa yang diinginkan Brecht dan Stanislavski. Meskipun kedua tokoh teater Internasional ini memiliki sistem yang berbeda dalam pengolahan aktornya, tapi penulis yakin bahwa keduanya sepakat bahwa seorang aktor yang baik harus memiliki fisik yang baik, itulah sebabnya latihan fisik penulis tempatkan pada poin utama.

\section{Latihan Imajinasi}

Di dalam metode Stanislavski, banyak sistem latihan yang mengarahkan para aktornya untuk melakukan olah Imajinasi. 
Oleh sebab itu seorang calon aktor terutama yang akan melakukan pementasan monolog sudah pasti olah imajinasi adalah kebutuhan selanjutnya yang harus dipenuhi, sebab sebagai calon aktor yang bermain sendirian di atas panggung, apabila miskin imajinasi di atas panggung bisa dipastikan akan membuat pementasan tersebut menjadi hambar, tanpa rasa dan tanpa daya pukau. Hal ini bahkan dinyatakan langsung oleh Stanislavski dengan memberikan ilustrasi tentang seoang aktor tua Perancis, Coquelin yang menciptakan modelnya dalam imajinasinya, dan seperti seorang pelukis ia teliti setiap segi dan cirinya, lalu ia pindahkan, bukan ke atas kanvas, tapi kedalam dirinya sendiri, ia melihat kostumnya, lalu ia kenakan, ia melihat langkahnya lalu ia tiru, ia melihat raut muka tokohnya lalu ia sadur pada dirinya sendiri dan bahkan ia bersuara seperti tokoh yang ia dengar dan ia membuat pribadi tokoh yang ia ciptakan dan menyerahkan sukmanya pada tokoh yang ia perankan, hingga akhirnya penonton meyakini bahwa yang ia hadirkan adalah tokoh bukan dirinya lagi ( Sani, 21: 2007). Melalui kutipan ini saja, penulis merasa optimis bahwa calon aktor yang ingin melakukan pementasan monolog sudah tahu apa yang harus ia lakukan untuk menciptakan tokohnya, hingga ia bisa "menjadi tokoh" dengan terus berlatih.

Oleh sebab itu latihan imajinasi menjadi penting sebagai teknik seorang aktor untuk melakukan pementasan monolog. Dalam sistem Stanislavski, hal ini penting untuk diketahui oleh seorang calon aktor sebagai bekal dalam dunia seni peran. Hal ini juga ditegaskan oleh Suyatna Anirun, dalam bukunya Menjadi aktor, pengantar kepada seni peran dan sinema. (1998), STB bekerjasama dengan Taman Budaya Jawa Barat dan PT Rekamedia Multiprakarsa. Sumbangan Suyatna Anirun dalam bentuk metode persiapan seorang manusia dalam menyiapkan diri untuk menjadi aktor/aktris. Buku teks akting yang mampu memperlebar kemampuan seorang yang menggeluti bidang akting, karena dalam buku ini tertulis banyak teknik berakting baik itu secara teoritis maupun praktis. Hampir setiap bab dari buku ini telah di uji oleh kenyataan, seperti yang telah di ketahui bahwa Sdr. Suyatna Anirun selain sutradara sejak SMA juga seorang dosen di bidang pemeranan dan penyutradaraan di STSI (Sekolah Tinggi Seni Indonesia) Bandung, dan pernah juga di IKJ (Institut Kesenian Jakarta) mengatakan;

Media dalam seni peran adalah diri si pemeran sendiri yakni, tubuh dan sukmanya, sebab pada tubuh ada panca indra, anggota tubuh dan peralatan vokal (suara). Di dalam sukma ada semangat/kemauan, imajinasi, emosi, daya ingat dan intelegensia, seluruhnya adalah peralatan ekspresi yang menunjang ketrampilan ketika melaksanakan tugas sebagai seorang seniman pemeranan, dalam kondisi yang direncanakan atau tidak direncanakan (Anirun, 43: 1998). Berdasarkan pernyataan dua seniman ini Stanislavski dan Suyatna Anirun maka, latihan berimajinasi adalah teknik yang penting untuk dikuasai seorang aktor. Karena imajinasi inilah sumber kreativitas seorang calon aktor untuk berkreasi menciptakan inovasi dalam penciptaan tokoh untuk kebutuhan pementasan monolog.
3. Latihan olah vocal
Olah vocal adalah hal yang paling penting untuk di kuasai oleh seoarang aktor, 
sebab vokal adalah salah satu media penyampai pesan setelah tubuh, meskipun saat sekarang ini panggung telah mendapatkan bantuan teknologi untuk membantu para aktor dalam menyampaikan pesan melalui vocalnya. Namun yang perlu di perhatikan lebih dalam ialah, bahwa totalitas dalam olah vocal seorang aktor di atas panggung bukanlah persolan apakah vocal aktor itu keras saja, melainkan totalitas yang diharapkan vokal sang aktor bisa menyatu dengan irama musik, permainan, penekanan, interjeksi, dan aura vocal yang bisa membisikkan pesan sampai ke relung hati penonton yang paling dalam. Itulah dalam teknik peran Stanislavski ditekankan kepada aktornya bahwa seorang aktor untuk latihan bernyanyi, menari dan senam harus di lakukan setiap hari;

Pelajaran bernyanyi, senam, menari dan main anggar (untuk aktor Indonesia boleh Silat). Pelajaran ini akan diberikan setiap hari, karena pengembangan otot-otot tubuh manusia memerlukan latihan yang sistematis dalam jangka waktu yang lama (Sani, 31: 2007).

Sambil menghapalkan naskah untuk mementaskan monolog, teknik yang telah disampaikan di atas tentu saja adalah teknik dasar yang harus disiapkan oleh seorang aktor terlebih dahulu. Adapun pentingnya olah vokal seperti yang dikatakan oleh RMA. Harymawan, dalam bukunya Dramaturgi, 160: 1993) yakni: bahwa suara itu bisa menghidupkan bahasa untuk di pahami orang lain sebagai petunjuk praktis atas penggambaran suasana hati manusia seperti marah, riang, susah dan sebagainya. Oleh sebab itu, target seorang aktor dalam olah vocalnya ialah bisa membedakan teksture, intonasi, stress, mood, pacing dan accent dalam berkata-kata. Di dalam buku ini juga banyak menuliskan tentang teknik bagaimana seorang aktor mengasah ketrampilannya dalam berakting, dan teknik berlatih menjadi aktor yang profesional dan proporsional. Vocal yang terolah juga bisa memberikan identifikasi tokoh.

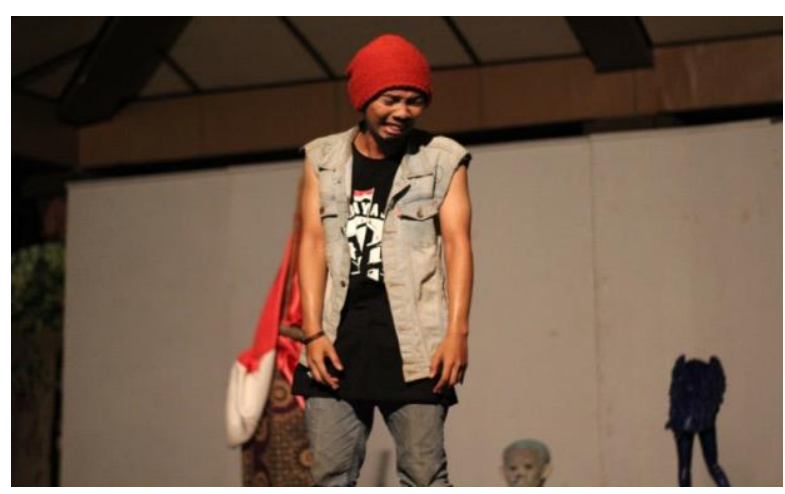

Gambar 2. Pementasan Monolog berdasarkan teknik Stanislavski dengan judul Bangkit Pemuda Oleh Abiyan Renardi, karya: Roci Marciano (foto oleh: rifah Isyah; 2019).

Apabila seorang aktor telah sukses melatih vocalnya, maka ia tidak perlu lagi khawatir untuk menerima peran apapun yang datang padanya. Sebab sudah semestinya seorang aktor yang baik bisa menguasai seni acting, dancing dan singing. Menari, bernyanyi dan berakting memang tidak mudah, oleh sebab itu latihan adalah salah satu kunci untuk menyempurnakan kemampuan seorang aktor, jika semua sudah terolah, maka kata-kata aktor bisa menjadi kendaraan imajinasi bagi penonton, dan tubuhnya menjadi kendaraan visual bagi penonton.

Selanjutnya penulis akan memaparkan tiga teknik berdasarkan hasil penelitian di buku Building A Character (Pembangunan Watak). Di dalam buku ini ditemukan teknik seorang aktor yang apabila ingin memukau penonton televisi, mau menjadi aktor dan 
aktris sukses dan mau menjadi singa podium. Buku ini juga memberikan pedoman bagi siapa saja yang ingin memukau publik entah sebagai aktor/aktris, pembawa acara, penceramah, pengajar, juru kampanye, pemasar ataupun humas. Buku ini juga mengupas berbagai topik yang menyangkut kesiapan intelektual, fisik, spiritual dan emosional seorang aktor secara rinci. Dengan gaya dialog antara guru dan murid. Karena di buku ini Stanislavski menunjukkan langkah demi langkah untuk menggerakkan publik pada tawa, air mata, dan emosi-emosi yang tak terlupakan.

Namun secara spesifik untuk teknik kebutuhan monolog memang belum ada, sebab secara tidak langsung yang dipaparkan dalam buku ini adalah kebutuhan untuk calon aktor secara umum. Sehingga dalam penelitian ini penulis akan mengembangkan sistem Stanislavski ini dalam Penemuan Teknik Peran Seorang Aktor Untuk Pementasan Monolog. Penulisan teknik berdasarkan buku Building A Character (Pembangunan Watak) ini tetap lanjutan step by step dari apa yang telah penulis paparkan di atas yang bersumber melalui buku PSA. Meskipun di dalam buku ini tidak semua teknik yang tertera akan diulas, tetapi penulis menyampaikan sesuai dengan kebutuhan dasar seorang aktor saja, baik itu secara teknik dan teknis apa saja yang diperlukan untuk kebutuhan monolog, maupun kebutuhan standar penulisan jurnal yang telah dibatasi dengan jumlah halaman. Penulis tetap berharap para pembaca menemukan buku tentang teknik monolog hasil penelitian penulis.

\section{Analisis Tokoh}

Bagi orang teater, kata analisis tokoh tentu saja sudah tidak menjadi kata yang asing, sebab sebagai seorang aktor, analisis tokoh adalah kebutuhan dasar yang harus dikerjakan oleh seorang calon aktor, karena dalam analisis ini pula keilmuan teater maupun keaktoran itu akan terasa berguna manfaatnya sebagai peningkatan kecerdasan intelegensia manusia yang bergelut dalam dunia seni peran. Analisis tokoh adalah kajian mendalam yang dilakukan oleh seorang aktor untuk mengetahui siapa tokoh yang akan ia mainkan, jika dalam konsep teater realisme, khususnya yang menggunakan metode Stanislavski, maka dikenal dengan analisis tiga dimensi tokoh (3D) yakni; 1. Aspek fisiologi, 2. Aspek sosiologi, 3. Aspek Psikologi. Tiga dimensi tokoh ini akan saling berkaitan satu sama lain, sebab tokoh yang dimainkan oleh seorang aktor, tentu saja tidak lepas dari tiga aspek dimensi dasar manusia di dalam kehidupan. Sehingga apabila aktor telah menemukan tokoh yang akan ia mainkan maka perwatakanpun bisa dikembangkan, seperti yang dikatakan Stanislavski:

Kita mengembangkan watak lahiriah dengan sumber dari diri kita sendiri, selain dari orang lain, dari kehidupan nyata atau imajiner, seturut intuisi dan amatan kita atas diri sendiri dan orang lain. Kita memperolehnya dari pengalaman hidup kita sendiri atau pengalaman teman-teman kita, dari foto-foto, lukisan, sketsa, buku, cerita, novel, atau suatu peristiwa sederhana-sama saja. Satu-satunya syarat yang harus dipenuhi adalah bahwa selama melakukan penelitian lahiriah ini kalian tidak boleh kehilangan diri batiniah kalian (Stanislavski, 7: 2008).

Bedasakan kutipan di atas maka semakin jelas bahwa pentingnya analisis tokoh, secara 
tidak langsung untuk melakukan koneksi tehadap diri aktor itu sendiri, setidaknya sang aktor bisa merasakan apa yang akan ia rasakan oleh tokoh yang akan ia mainkan, sehingga ekspresi yang akan dihadirkan lewat akting akan bisa dirasakan oleh penonton sebagai suatu kejujuran dan kebenaran. Lantas petanyaannya? Bagaimana dengan cara akting-akting yang belum pernah dilakukan, misalnya mendapatkan tokoh membunuh manusia? Tentu saja seorang aktor yang cerdas seharusnya jangan penah membunuh manusia jika ingin memerankan tokoh seorang pembunuh. Namun untuk membantu aktor tesebut untuk mendapatkan perasaan dalam akting membunuh, maka bisa dialihkan dengan membunuh hewan yang paling dibenci, misalnya seperti yang pernah penulis eksplorasi. Penulis paling benci dengan seekor tikus got, sehingga muncul keinginan untuk membunuh tikus tersebut bila melihatnya, dan ketika membunuh tikus got tersebut ada rasa puas dan lega di dalam diri penulis.

Untuk kasus ini penulis juga menghimbau kepada para calon aktor agar berhati-hati dalam membunuh hewan, sebab saat sekarang ini banyak UU yang sudah mengatur perlindungan terhadap hewan, begitu juga dengan para komunitas pecinta hewan-hewan tertentu, harapannya dalam melakukan tahap-tahap tertentu untuk eksplorasi akting, perlu kecerdasan agar tidak menyinggung pihak lain. Penulis juga menghimbau kepada calon aktor yang mendapatkan peran pembunuh, bisa melakukan wawancara terhadap para pembunuh, atau membaca catatan-catatan di kepolisian sebagai bentuk observasi lapangan. Wawancara terhadap korban pembunuhan yang selamat penulis rasa juga bisa membantu seorang aktor untuk mengeksplorasi tokoh pembunuh yang akan ia mainkan. Bila bercermin pada aktor luar Negeri, mereka berani membeli mayat tanpa status untuk dibunuh, baik itu ditembak, ditusuk atau disiksa, tetapi bagi aktor yang tidak punya modal seperti aktor profesional yang penulis jelaskan, maka cukup lakukan apa yang sudah penulis paparkan dengan memperkuat ingatan emosi.

Nah perasaan inilah yang kemudian harus diingat oleh sang aktor untuk ia terapkan dalam tokoh pembunuh yang akan ia mainkan, tentu saja tingkat kewajaran dalam cara membunuh bisa dilakukan dengan menganalisis tokoh tersebut secara lebih dalam, dan melatihkannya sewajar mungkin, agar aktor tersebut bisa menjadi tokoh seperti yang igin diwujudkan. Akting menjadi yang diharapkan oleh Stanislavski, yaitu bertujuan untuk membenarkan laku, pembenaran ini tidak hanya berlaku bagi motivasi, tetapi juga bagi usaha untuk mempertahankan laku. Mencari inspirasi, bagi aktor gaya Stanislavski dengan diam-diam menunjukkan kebenaran laku yang ada. Garis laku menghilangkan bangunan sosial dan dengan demikian mengubah alam realita secara politis. Membenamkan penonton kedalam suatu arus tujuan yang berubah beserta konsekuensinya yang muncul, perubahan tersebut akan mengembangkan ilusi bahwa gambaran sekuens penyebabnya dalam beberapa hal bersifat absolut. Sekuens dimana a menyebabkan b menyebabkan c secara berlebihan menyatakan bahwa, menghadirkan a (kondisi yang ada), c pasti terjadi (Mitter, 94: 199). 
Apabila seorang aktor telah melakukan analsis lebih mendalam, maka tinggal melakukan praktek, karena apalah artinya kerja kreatif bila tidak dipraktekkan, teutama dibidang seni yang khususnya teater. Praktik adalah puncak dari keja kreatif, dan seorang aktor bisa melakukan analisis ulang apabila terjadi kesalahan dalam penciptaan tokohnya. Karena apabila pementasan telah belangsung, maka aktor tesebut harus ikhlas dengan tokoh yang telah ia lahirkan.

\section{Olah Rasa}

Pada dasarnya di dalam buku Stanislavski edisi membangun tokoh ini, tidak ada kata yang menuliskan olah rasa secara spesifik seperti yang penulis tulis menjadi sub judul, namun berdasakan dari pembacaan dan analisis yang penulis lakukan, secara tidak langsung apa yang dilakukan oleh Stanislavski secara teknik mengarah kepada olah rasa. Sebab secara tidak langsung seorang aktor dituntut benar-benar merasakan apa yang dirasakannya ketika berakting, agar perasaan aktor dalam menghidupkan tokoh tersbut bisa dirasakan oleh penonton. Olah rasa sangat berhubungan erat dengan batin seorang aktor, sebab hubungannnya dengan perasaan, tentu saja motiv yang lahir sudah semestinya dari dalam diri aktor atau yang mengimpuls sang aktor untuk bergerak. Misal ketika aktor merasakan lapar, maka muncul keinginan untuk makan, tentu saja rasa laparlah yang lebih dulu hadir di dalam diri sang aktor baru kemudian ia bergerak untuk makan, jika tidak ada rasa lapar, maka akting makan yang dihadirkan oleh seorang aktor tentu saja bukanlah akting tokoh yang kelaparan melainkan seorang tokoh yang mungkin hanya berbasa-basi atau sekedar untuk menghormati yang menawarkan makan.

Di dalam buku membangun tokoh yang ditulis Stanislavski ini juga ada banyak metode yang mendekati pada olah rasa tersebut, tetapi dalam kesempatan ini penulis memilih salah satu berdasakan yang paling disukai, semoga hal ini juga bermanfaat bagi calon aktor yang ingin melakukan monolog, dan membaca jurnal ini, sebab sistem latihan ini juga efektif dilakukan oleh calon aktor seorang diri seperti:

Berlatih dengan musik, seorang aktor mendengarkan alunan musik, merasakan dan kemudian mengikuti keinginan dari lubuk hati untuk bergerak. Seorang aktor harus bisa merasakan energi bergeak dengan gagah dan indah dalam alunan yang tak terputus. Karena itulah, gerak yang menciptakan keleluasaan, keliatan gerak tubuh yang sangat dipelukan. Diusahakan alur batin tersebut berasal dari lubuk terdalam diri aktor, dan energi yang dihasilkan penuh dengan rangsangan perasaan, kehendak dan kecerdasan. Ketika dengan bantuan latihan sistematis, calon aktor terbiasa dan merasa nikmat mendasarkan laku kalian pada alur batin ketimbang alur lahir, maka aktor akan mengetahui apa arti emosi gerak itu sendiri (Stanislavski, 79: 2008).

Kutipan di atas mempertegas bahwa emosi gerak laku dan kata yang diekspresikan seorang aktor hendaklah benar-benar bisa dirasakan penonton, karena apabila emosi ini bekerja di dalam diri aktor, secara tidak langsung akan melahirkan irama permainan yang enak untuk dinikmati, meskipun dalam berakting tetap seorang aktor tidak larut dalam emosi yang tidak tekendali, sebab apabila kesadaran emosi tidak digunkan maka akan tejadi kekacauan dalam permainan, siaktor akan sibuk dengan diri sendiri, tidak 
memikikan emosi tokoh yang ia perankan, maka koneksi rasa antara aktor dan penontonpun akan terputus, seperti sinyal handphone yang tidak bisa berkoneksi dan pesanpun tidak tersampaikan dengan baik.

6. Uji Pencapaian Dalam Mewujudkan Tokoh Pada Saat Pementasan

Ketika calon aktor telah melakukan lima hal penting yang telah dipaparkan di atas, maka perlu rasanya menguji diri untuk melakukan praktek yaitu, dengan cara mewujudkan tokoh. Hal ini berguna untuk mengukur capaian calon aktor, dan mengujikannya pada saat pementasan, apakah aktor tesebut berhasil atau tidak menerapkan sistem Stanislavski untuk kepentingan monolog? Memang pada dasarnya apa yang telah penulis paparkan pada junal ini belum seutuhnya lengkap, akan tetapi secara esensi hal ini bisa membantu para calon aktor yang ingin melakukan monolog. Adapun secara metode latihan untuk mewujudkan tokoh yang diinginkan seorang aktor ialah, harus tabah dan ikhlas untuk melakukan eksplorasi terhadap diri sendiri, seperti mendandani diri sesuai dengan tokoh yang diharapkan. Seorang aktor yang belum memiliki kepercayaan tehadap diri sendiri juga bisa menyamar menjadi orang lain sebagai bentuk latihan, hal ini juga diterapkan oleh Stanislavski dalam sistem pelatihannya. Akan tetapi secara teknis orang lain yang akan dihadirkan telah diobservasi dan dianalisis terlebih dahulu dengan baik, sehingga hasil kerja seorang aktor dalam menghadirkan tokoh tersebut di atas panggung akan tampak, meskipun tidak sama persis seperti yang diharapkan penonton, sebab sang aktor tesebut juga menghidupkan imajinasinya dan menghadirkan tokoh tesebut juga atas kreasi dan imajinasinya sendiri (sang aktor adalah pencipta/kreator). Kalimat ini yang perlu ditegaskan di dalam diri seorang calon aktor, bahwa AKTOR ADALAH KREATOR.

Uji pencapaian ini penting, karena seorang aktor akan bisa menilai dirinya dari pandangan orang lain, yaitu penonton, apakah ia berhasil atau tidak dalam menghidupkan tokohnya. Sebab apalah artinya peran yang dimainkan apabila hanya untuk dinikmati oleh diri sendiri, dan puas atas pujian diri sendiri. Oleh sebab itu dalam hal ini penulis menganjurkan pada para aktor, untuk mengujikan dirinya dengan para pakar keaktoran, agar pencapaian dalam mewujudkan tokoh bisa didiskusikan setelah pementasan belangsung, karena seni peran ini telah menjadi salah satu ranah keilmuan yang seharusnya menjadi pembelajaran wajib di dalam kehidupan dan pendidikan. Hanya saja pemerintah tampaknya belum menyadari akan pentingnya pembelajaran seni peran ini. Mengapa penulis mengatakan penting, sebab pada akhirnya setiap manusia di dunia ini akan menjalani perannya masing-masing. Beruntung mereka yang pernah di tempa di teater, setidaknya di dalam kehidupan nyata mereka bisa dengan ikhlas dan tulus menjalankan perannya, dan menggunakan ilmu keaktorannya untuk betahan hidup.

Di dalam pementasan seorang aktor hendaknya bisa menghidupkan keadaan kreatifitas lahiriah dan batiniahnya, sehingga tiga kekuatan motif dalam kehidupan batin bisa dirasakan, sepeti: Pikiran (Cipta), Kehendak (Karsa) dan Perasaan (rasa), sehingga agar tujuan dan sasaran menjadi hidup, seorang aktor harus 
memiliki kesadaran tentang yang sejati, rasa yakin akan apa yang sedang dilakukannya, aktingpun tidak lagi menjadi pura-pura, melainkan tindakan yang diyakini sebagai kebenaran (Stanislavski, 343-344: 2008).

Penyataan Stanislavski ini adalah kunci dalam berakting, dan apabila mengamati para aktor di dunia ini ketika melakukan tugasnya dalam seni peran, maka sangat berkaitan erat dengan apa yang telah dinyatakan Stanislavski di atas. Sehingga jurus yang bisa dilakukan oleh seorang aktor sebagai solusi apabila ia melakukan suatu kesalahan dalam berakting saat pementasan, dengan cara meyakini apa yang ia lakukan sebagai kebenaran (sederhananya meyakini kesalahan tersebut sebagai suatu kebenaran), karena, meskipun ia melakukan kebenaran akting tapi ia menyajikannya dengan keragu-raguan, maka penonton akan merasakan apa yang ia lakukan adalah suatu kesalahan. Oleh sebab itu seorang aktor dalam hal ini diwajibkan untuk belajar berakting dengan rasa keyakinan dan kebenaran, kalau bisa hingga membuat penonton lupa bahwa ia sedang menyaksikan petunjukan, karena jika bisa, buatlah seorang penonton seakan menjadi saksi atas peristiwa yang nyata di hadapannya.

Hal inilah yang menyebabkan aktoraktor disebut berperan dengan totalitas dalam pencipataan tokohnya, baik itu melakukan pengurusan badan, penggendutan maupun eksplorasi sesuai kebutuhan penokohan yang ingin dihadirkan. Sebab pada prakteknya banyak aktor salah mengartikan totalitas dalam dunia seni peran, hingga kadang sebagai penonton melihat aktor tersebut menjadi over akting. Padahal totalitas yang diharapkan dalam seni peran adalah, seorang aktor bisa bermain wajar ("PAS"). Lantas bagaimana ukuran kesuksesan seorang aktor dalam seni peran? Tenang saja, bahwa yang namanya rasa hanya bisa dinilai dengan rasa, sebab rasa tidak bisa dikalkulasi dengan angka dan logika dan pada akhirnya, pecayakanlah semua penilaian pada penonton atas suatu perasaan yang bisa dirasakan, karena rasa pada dasarnya tidak pernah telibat dalam kedustaan.

\section{KESIMPULAN}

Sebuah karya seni seperti sistem Stanislavski tentu saja telah banyak groupgroup teater yang menerapkannya, baik itu di dalam negeri maupun di luar negeri, khususnya Rusia tempat asalnya penulis buku itu sendiri. Namun belum ada yang secara spesifik merangkum dan mengembangkannya untuk kebutuhan pementasan monolog. Pada kesempatan penyusunan Pengembangan Teknik Peran Seorang Aktor Untuk Pementasan Monolog Melalui Sistem Stanislavski An Actor Prepares dan Building Character kali ini, penulis akan menjadikannya sebagai objek penelitian untuk kebutuhan aktor yang akan melakukan pentas monolog.

Berdasarkan atas apa yang telah diuraikan di atas, yang berawal dari pertanyaan, Bagaimana mengembangkan metode teknik peran Stanislavski untuk kebutuhan pementasan monolog? Bagaimana menyaring teknik peran yang dicetuskan oleh Stanislavski dalam bukunya actor and preapere dan Building A Character untuk kebutuhan teknik peran monolog? Setidaknya bisa penulis simpulkan bahwasanya teknik yang telah dicetuskan oleh Stanislavski ini 
masih bisa dikembangkan dengan berbagai macam cara, bahkan juga bisa diadopsi untuk kebutuhan aktor Indonesia. Sebelumnya penulis menyepakati terlebih dahulu bahwa pementasan monolog adalah satu orang manusia yang disebut sebagai aktor, berakting di atas panggung, dengan menghidupkan satu tokoh, dan aktor tersebut menjadi tokoh, karakter yang dihadirkan bisa saja bermacammacam, akan tetapi yang tampak hanya satu tokoh. Jika tokoh tersebut menceritakan orang lain maka ia tidak perlu berubah menjadi tokoh ke dua, akan tetapi bisa ditirukan tanpa harus persis seperti tokoh kedua, ketiga dst. Jika ingin menceritakan tokoh lain, tokoh utama yang dimainkan tidak hilang, maka hal ini disebut dengan pentas monolog, tanpa ada bantuan suara manusia lainnya dari luar diri aktor utama.

Adapun hal yang penting didapatkan oleh calon aktor selama proses penelitian ini, diantaranya ialah melatih diri untuk menciptakan koneksi terhadap orang lain (bisa penonton). Jika dijumlah secara komulatif, maka teknik peran yang terdapat dalam dua buku Stanislavski ini berjumlah sekitar, enam ratus teknik berlatih untuk menciptakan tokoh dalam pementasan teater. Namun penulis perlu menyaring beberapa saja demi efisiensi kerja calon aktor yang ingin melakukan proses menuju pementasan monolog.

Latihan ini digunakan demi terjadinya koneksi antara aktor dengan penonton, sehingga pesan yang ingin disampaikan bisa dibaca dan dirasakan oleh penonton. Aktor sebagai pengirim pesan harus bisa menghidupkan "wifi" di dalam tubuhnya, yakni sinyal yang ia ciptakan di dalam latihan seperti yang telah di paparkan pada bab pembahasan. Adapun sinyal di dalam diri aktor tersebut ialah tubuh, imajinasi, vocal, intelegensia dan rasa yang terolah dengan baik. Apabila sinyal aktor telah menyala dengan kapasitas yang kuat, maka ketika pesan melalui tokoh yang dimainkan akan sampai dengan indah pada penonton dan akan mudah diterima, dan penonton sebagai penerima pesan juga bisa merasakan dengan baik apa yang telah dikirim aktor terhadap panca indranya. Ibarat satu pesan yang bisa disampaikan dalam grup chatingan (WA), dan yang menjadi grupnya dalam hal ini adalah penonton. Seharusnnya seorang aktor lebih mudah menggenggam hati penonton dengan aktingya, sebab apa yang disajikan sifatnya langsung tanpa media dan perantara seperti hp dan alat teknologi lainnya, inilah keunikan teater.

\section{DAFTAR PUSTAKA}

Abdullah, T Imron. (2000). (Editor Nur Sahid), Interkulturalisme dalam Teater, Yayasan Untuk Indonesa; Yogyakarta.

Alterman, Glenn. (2005). Creating your own monologue, Published by Allworth Press, 10 East 23rd Street, New York, NY 10010.

Anirun,Suyatna. (1998). Menjadi Aktor. Bandung : Studi Teater Bandung bekerjasama dengan Taman Budaya Jawa Barat Dan PT Rekamedia Multiprakarsa.

Anwar,Chairul. (2005). Drama Bentuk Gaya dan Aliran, Yohyakarta : Elkaphi

Harymawan, RMA. (1998). Dramaturgi, bandung: CVRosda.

Kernoddle, George R. (1996). Invitation To

The Theater, Terjemahan. Yudiaryani, 
M.A. UPT Tahun: 2005, 2007, 2008. Perpustakaan ISI Yogyakarta.

Miiter, Shomit. (2002). Sanilavsky, Brecht, Grotowsky, Brook, system pelatihan lakon. Yogyakarta: MSPI.

Moleong, M. (2007). Metodologi Penelitian Kualitatif. Bandung: PT Remaja Rosdakarya.

Ratna, Kutha, Nyoman. (2013), Glosarium, 1250 Entri, Kajian Sastra, Seni, Dan Sosial Budaya, Pustaka Pelajar, Yogyakarta.

Riantiarno, Nano, Bakdi, Soemanto. Sphinx Triple X, Antologi Monolog Anti Budaya Korupsi, Jomboran, Sidoarum.

Shengold, Nina. (1987). The Actor's Book Of Contemporary Stage Monologues, A Smith And Krausinc Book. Penguin Books, 40 West 23RD Street. New York, New York 10010. U.S.A.

Stanislavski, Constantin. (2008). Building Character. Diterjemahkan oleh, B. Very Handayani, Dina Octaviani, Triwahyuni. Membangun Tokoh. PT. Gramedia, Jakarta.

Stanislavski, Constantin. An Actor Preapers. Diterjemahkan oleh, Asrul Sani. (2007). Persiapan seorang aktor. 2007 (Cetakan kedua). PT. Bastela Indah Prinindo, Jakarta.

Sugiyono. (2011). Metode Penelitian Pendidikan (Pendekatan Kuantitatif, Kualitatif dan R\&D). Bandung : Alfabeta

Yudiariani. (2002). Panggung Teater Dunia, Yogyakarta: Pustaka Gendho Suli. 